\title{
Complement-induced Glomerular Epithelial Cell Injury \\ Role of the Membrane Attack Complex in Rat Membranous Nephropathy
}

Andrey V. Cybulsky, Helmut G. Rennke, Irwin D. Feintzeig, and David J. Salant
Evans Memorial Department of Clinical Research and Department of Medicine at University Hospital, Boston University
Medical Center, Boston, 02118; Department of Pathology, Brigham and Women's Hospital, Boston, Massachusetts 02115

\section{Abstract}

In passive Heymann nephritis (PHN) in rats, antibody (antiFx1A) reacts in situ with a glomerular epithelial antigen and induces complement (C)-mediated cell-independent proteinuria. To assess the role of the membrane attack complex (MAC), we determined the need for $\mathrm{C} 8$ in the pathogenesis of proteinuria in an autologous-phase model of PHN. Isolated rat kidneys, containing nonnephritogenic, non-C-fixing $\gamma 2$ sheep anti-Fx1A (planted antigen), when perfused in vitro with $\mathrm{C}$-fixing guinea pig anti-sheep IgG and a source of C (fresh human plasma $50 \%$ $\mathrm{vol} / \mathrm{vol}$ in buffer containing bovine serum albumin), developed marked proteinuria after $20 \mathrm{~min}(0.58 \pm 0.08 \mathrm{mg} / \mathrm{min} \cdot \mathrm{g}, \boldsymbol{n}=8)$ that increased further to $3.20 \pm 0.93 \mathrm{mg} / \mathrm{min} \cdot \mathrm{g}$ after $80 \mathrm{~min}$. In contrast, identical kidneys perfused with antibody and heat-inactivated or C8-deficient human plasma and normal kidneys perfused with antibody and fresh plasma excreted only $0.27 \pm 0.03$ $(n=6), 0.27 \pm 0.04(n=5)$, and $0.40 \pm 0.05 \mathrm{mg} / \mathrm{min} \cdot \mathrm{g}(n=6)$ after $20 \mathrm{~min}$, and $0.13 \pm 0.02,0.22 \pm 0.03$, and $0.32 \pm 0.05 \mathrm{mg} /$ $\mathrm{min} \cdot \mathrm{g}$ after $80 \mathrm{~min}$, respectively. When C8-deficient plasma was reconstituted with sources of $\mathrm{C8}(n=3)$, proteinuria was restored to the level observed with fresh normal plasma. Differences in protein excretion could not be explained by quantitative differences in glomerular antigen or antibody content. Extensive ultrastructural damage to glomerular visceral epithelial cells was exclusively seen in antigen-containing kidneys perfused with antibody and C8-replete plasma. Thus, glomerular injury in this model results from an antigen-specific, antibody-directed, C8dependent reaction involving assembly of the MAC. The ultrastructural findings argue in favor of MAC-induced cytotoxicity of the glomerular visceral epithelial cells.

\section{Introduction}

In addition to the well-known hemolytic action of the C5b-9 membrane attack complex (MAC) ${ }^{1}$ of complement (C), its non-

Address reprint request to Dr. Salant, Renal Section, Boston University Medical Center, 80 E. Concord Street, Boston, MA 02118.

Received for publication 6 August 1985 and in revised form $25 \mathrm{No}-$ vember 1985 .

1. Abbreviations used in this paper: $\mathrm{C}$, complement; $\mathrm{C} 8 \mathrm{D} \alpha-\gamma$, deficiency of the $\alpha-\gamma$ unit of C8; C8D $\beta$, deficiency of the $\beta$-unit of C8; $\mathrm{CH}_{50}$, total hemolytic complement activity; $\mathrm{C}_{\text {inulin }}$, inulin clearance; $\mathrm{EM}$, electron microscopy; $F_{R_{\mathrm{Na}}}$, fractional reabsorption of sodium; GBM, glomerular basement membrane; HI, heat inactivated; IF, immunofluorescence; IPK, isolated perfused rat kidney; KHB, Krebs-Henseleit buffer; MAC, membrane attack complex of complement; $\mathrm{MN}$, membranous nephropathy; PHN, passive Heymann nephritis; RVR, renal vascular resistance.

J. Clin. Invest.

(c) The American Society for Clinical Investigation, Inc. 0021-9738/86/04/1096/12 \$1.00

Volume 77, April 1986, 1096-1107 lytic cytopathic effects on nucleated cells are currently receiving considerable attention (1-3). A possible example of the pathophysiological consequences of these effects is provided by observations that glomerular injury in the passive Heymann nephritis (PHN) model of experimental membranous nephropathy $(\mathrm{MN})$ in the rat is $\mathrm{C}$-mediated but leukocyte-independent $(4,5)$. These findings have recently been extended in a model of $\mathrm{MN}$ induced by immunization of normal and C6-deficient rabbits with cationized bovine serum albumin (BSA) (6) and in PHN rats depleted of $\mathrm{C6}$ (7). In both situations, C6-deficient animals failed to develop the features of glomerular injury that occurred in their C-replete counterparts. Thus, the evident lack of chemotactic effects of $\mathrm{C}$ in PHN and requirement for $\mathrm{C6}$ in these models suggested a role for the terminal $\mathrm{C}$ pathway. Additional circumstantial evidence that the MAC may be responsible for organ damage is provided by several recent immunohistologic and morphologic studies that have documented the presence of terminal C components and the MAC in lesions of patients (8-12) and experimental animals (13-18) with various forms of tissue injury including rat $\mathrm{MN}$ (15-18). However, the primary target and mechanisms of C-induced injury that lead to altered glomerular permeability remain unknown and direct proof that the MAC is involved in this process is lacking.

The aim of this study was to obtain definitive functional evidence for or against the role of the MAC in glomerular capillary wall injury using a variant of the rat PHN model. The rationale is based on the fact that membrane-bound $\mathrm{C} 5 \mathrm{~b}-7$ has no deleterious effect on cell membrane integrity, whereas binding of $\mathrm{C} 8$ to the complex results in membrane damage, a process that is accelerated by the subsequent binding of C9 (19-21). C8 is thus the keystone to formation of a cytopathic complex. Inasmuch as there are no $\mathrm{C} 8$-deficient (C8D) rat strains and specific depletion of C8 is difficult to achieve in vivo (Salant, D. J., unpublished observations), we adopted a passive autologous-phase model of PHN in the isolated perfused rat kidney (IPK). The IPK has been successfully used in previous immunologic studies (22-27) and has been accepted as a valid model for investigating changes in glomerular permeability (24-27). In keeping with observations in the autologous phase PHN model in vivo (5, 28), antibody-directed, C-mediated glomerular injury was reproduced in the IPK by perfusing kidneys with antibody and human plasma replete in all $\mathrm{C}$ components but not with heatinactivated $(\mathrm{HI})$ plasma. Furthermore, the absence of injury in kidneys perfused with C8D human plasma and its restoration on reconstituting the $\mathrm{C}$ deficiency with a source of $\mathrm{C} 8$ established that assembly of the MAC is essential for the development of glomerular injury in rat $\mathrm{MN}$.

\section{Methods}

Kidney perfusion and perfusate composition. BSA (Miles Laboratories, Naperville, IL) perfusate was prepared by initially dialyzing a $20 \%$ BSA 
solution in Krebs-Henseleit buffer (KHB) against 10 vol of KHB for 48 $h$. The BSA was then diluted to a concentration of $80 \mathrm{mg} / \mathrm{ml}$ by additional $\mathrm{KHB}$ and amino acids. The final composition of KHB included (in millimoles per liter): $\mathrm{Na}, 140 ; \mathrm{K}, 4.8 ; \mathrm{Ca}, 3.0 ; \mathrm{Mg}, 1.2 ; \mathrm{Cl}, 119 ; \mathrm{HCO}_{3}, 25$; inorganic phosphate, $1.2 ; \mathrm{SO}_{4}, 1.2$; glucose, 5.0 ; and amino acids-leucine, 0.8 ; phenylalanine, 0.64 ; lysine, 2.0 ; methionine, 0.66 ; isoleucine, 0.6 ; valine, 0.66 ; histidine, 0.48 ; threonine, 0.48 ; tryptophan, 0.14 ; alanine, 4.0 ; glycine, 4.6 ; arginine, 1.0 ; proline, 0.62 ; tyrosine, 0.4 ; cysteine, 1.0 ; aspartate, 0.4 ; glutamate, 1.0 ; asparagine, 0.4 ; glutamine, 4.0 ; and serine, 2.0 .

Fresh frozen human plasma was provided by Dr. R. Valery of Naval Blood Research Laboratory, Boston, MA. Units of plasma that had been collected into citrate-phosphate-dextrose were pooled, treated with heparin $(6 \mathrm{U} / \mathrm{ml})$ and dialyzed for $24 \mathrm{~h}$ against $10 \mathrm{vol}$ of $\mathrm{KHB}$ without $\mathrm{Ca}$. For some experiments plasma was heat-inactivated at $56^{\circ} \mathrm{C}$ for $30 \mathrm{~min}$. C8D $\beta$ plasma was collected by plasmapheresis from an individual with a congenitally dysfunctional C8 molecule and was treated similarly to fresh plasma. The total absence of $\mathrm{C} 8$ hemolytic activity in this individual has been fully characterized $(29,30$-patient D.T.) and found to be due to deficiency of the $\beta$-subunit of the $\mathrm{C} 8$ molecule. In one experiment (see below), the C8D $\beta$ plasma was mixed with serum deficient in the $\alpha-\gamma$ C8 unit (30, patient R.G.) to reconstitute C8 activity. Prior to use, both BSA-KHB perfusate and plasma were filtered through a $0.45-\mu \mathrm{m}$ filter (Millipore Corp., Bedford, MA).

Experiments were carried out in an incubator that maintained a temperature of $37^{\circ} \mathrm{C}$. The perfusion circuit was driven by two pumps (Masterflex, Cole-Parmer, Chicago, IL) and consisted of two glass reservoirs, a glass film-oxygenator, an 8- $\mu \mathrm{m}$ Millipore filter, a flowmeter (Gilmont, Cole-Parmer), and a side-arm pressure gauge, all connected by Tygon $^{\mathbf{R}}$ tubing (Cole-Parmer). Glassware was siliconized and perfusate was gassed with $95 \% \mathrm{O}_{2} / 5 \% \mathrm{CO}_{2}$.

The isolated kidneys were perfused according to Nishiitsutsuji-Uwo et al. (31). Briefly, male Sprague-Dawley rats (CD, Charles River Breeding Laboratories, Wilmington, MA) weighing 275-335 $\mathrm{g}$ were anesthetized with an intraperitoneal injection of $3.6 \%$ chloral hydrate $(1.2 \mathrm{ml} / 100 \mathrm{~g})$. The right ureter was cannulated with PE-50 tubing after injection of 200 $\mathrm{mg}$ of mannitol intravenously. A glass cannula (P. Brooks, Ducklington, England) was passed retrograde through the superior mesenteric artery into the right renal artery without interrupting blood flow. While the kidney was perfused with BSA-KHB, the cannula was tied in place and the kidney and ureter were dissected free and mounted in the incubator.

After $5 \mathrm{~min}$, verapamil (Knoll Pharmaceutical Co., Whippany, NJ) was added to the BSA-KHB perfusate at a concentration of $10^{-4} \mathrm{M}$. Verapamil was required to prevent the development of intense vasoconstriction and renal shutdown, which universally occurred if plasma was added alone. After a further $5 \mathrm{~min}$ of perfusion, plasma was added $(50 \%$ $\mathrm{vol} / \mathrm{vol}$ ) to BSA-KHB. This resulted in a final albumin concentration of $60 \mathrm{mg} / \mathrm{ml}$, and the same electrolyte concentration as in KHB, except for $\mathrm{Ca}$ and amino acids that were reduced by $50 \%$. The perfusion pressure was adjusted to, and constantly maintained at $95-99 \mathrm{mmHg}$. After 10 min of stabilization, antibody was added and measurements were begun. The perfusion lasted 1 or $2 \mathrm{~h}$, with three or six urine collection periods, each 20 min in length.

Measurements. Inulin clearance $\left(\mathrm{C}_{\text {inulin }}\right)$ was measured with $\left[{ }^{3} \mathrm{H}\right]$ methoxy-inulin, or $\left[{ }^{14} \mathrm{C}\right]$ inulin (New England Nuclear, Boston, MA) during experiments involving ${ }^{125} \mathrm{I}$. Perfusate inulin concentration was determined at the midpoint of each collection period. Urine and perfusate samples were placed into scintillation fluid and counted in a beta-scintillation counter (Beckman Instruments, Inc., Fullerton, CA). Protein concentration was determined spectrophotometrically (Gilford Instrument Laboratories, Oberlin, $\mathrm{OH}$ ) at $\mathrm{OD}_{280}$, using a Labtrol (Dade Diagnostics, Agnada, PR) standard. Sodium was measured by a flame photometer (Instrumentation Laboratories, Lexington, MA). Perfusate flow rate was monitored constantly and renal vascular resistance (RVR) was calculated from: average perfusion pressure/perfusate flow rate $(\mathrm{mmHg} \cdot \mathrm{min} \cdot \mathrm{g} / \mathrm{ml})$. $\mathrm{C}_{\text {inulin }}(\mathrm{ml} / \mathrm{min} \cdot \mathrm{g})$, urine protein excretion $(\mathrm{mg} /$ $\min \cdot \mathrm{g})$, and fractional sodium reabsorption $\left(\mathrm{FR}_{\mathrm{Na}} \%\right)$ were calculated from standard formulas. Measurements are expressed as a function of kidney weight.

Production and characterization of antibodies. A sheep was immunized by repeated monthly injections of rat Fx1A, as previously described (4). The $\gamma 2$ IgG subclass was isolated by ion-exchange chromatography, heat-inactivated $\left(56^{\circ} \mathrm{C}, 30 \mathrm{~min}\right)$, concentrated, and stored, as described (4). On immunoelectrophoresis the fraction was shown to contain pure $\gamma 2$ sheep IgG.

Hartley guinea pigs (Charles River Breeding Laboratories) were immunized by four subcutaneous injections of purified sheep IgG in complete Freund's adjuvant (Difco Laboratories, Detroit, Mich). After 10 wk, antiserum was collected and stored at $-70^{\circ} \mathrm{C}$ until use. The concentration of anti-sheep IgG in whole antiserum was approximately 8.75 $\mathrm{mg} / \mathrm{ml}$ as determined by reverse radial immunodiffusion $(32,33)$, using affinity-purified antibody (see below) as the standard.

For iodination, guinea pig anti-sheep IgG was purified by affinity chromatography. Sheep $\gamma 2 \mathrm{IgG}$ was linked to cyanogen bromide (CNBr)Sepharose-4B (Pharmacia Fine Chemicals, Piscataway, NJ), as recommended by the manufacturer. After whole antiserum was passed through the column, the bound antibody was eluted with $1.75 \mathrm{M}$ KSCN. The eluted antibody was shown on immunoelectrophoresis to be pure, containing two subclasses of guinea pig IgG. By reverse radial immunodiffusion (32), its relative affinity for sheep IgG was $50 \%$ greater than that of whole antiserum.

Quantitation of glomerular antibody binding. The $\gamma 2$ fraction of Sh anti-Fx $1 \mathrm{~A}(10 \mathrm{mg})$ and affinity-purified guinea pig anti-sheep $\operatorname{lgG}(5 \mathrm{mg})$ were iodinated with $2 \mathrm{mCi}$ of ${ }^{131} \mathrm{I}$ and $1 \mathrm{mCi}$ of ${ }^{125} \mathrm{I}$, respectively (New England Nuclear), by the chloramine-T method (34). Specific activities were $3.8 \times 10^{4} \mathrm{cpm} / \mu \mathrm{g}$ of ${ }^{131} \mathrm{I}$ and $1.2 \times 10^{5} \mathrm{cpm} / \mu \mathrm{g}$ of ${ }^{125} \mathrm{I}$. The former was diluted with "cold" antibody before injection into rats. Iodinated and noniodinated guinea pig anti-sheep IgG had similar relative affinities for sheep IgG by radial immunodiffusion (32), and had similar indirect immunofluorescence titers against kidney tissue-bound sheep IgG.

To quantitate glomerular antibody binding, perfusate was sampled to measure the concentration of ${ }^{125} \mathrm{I}$-guinea pig anti-sheep IgG and kidneys were perfused with $100 \mathrm{ml}$ of saline at the end of the experiment. In pilot studies it was determined that after this, the nonspecific binding of antibody was insignificant. Glomeruli were then separated by differential sieving (35) and counted for ${ }^{125} \mathrm{I}$ and ${ }^{131} \mathrm{I}$ in a gamma-counter (Packard Instrument Co., Downers Grove, IL, or Searle Analytic Inc., Des Plaines, IL). Counts were corrected for decay, channel spillover, and perfusate antibody concentration. The number of glomeruli isolated from each kidney was determined by visual counting and glomerular binding of $\gamma 2$ sheep anti-Fx1A and guinea pig anti-sheep IgG was calculated as described (35) and expressed as micrograms bound per 38,000 glomeruli (the average number of glomeruli per rat kidney).

Hemolytic assays. The total hemolytic complement $\left(\mathrm{CH}_{50}\right)$ of each pooled plasma preparation was measured by a test tube method according to Kabat and Mayer (36), and was compared to fresh frozen serum of a single normal individual. For determination of $\mathrm{C} 8$ activity, sheep erythrocytes, sensitized with $\mathrm{C} 1-7$, were prepared by incubating erythrocytes with rabbit anti-sheep hemolysin (A) (Difco, $20 \mathrm{~min}, 4^{\circ} \mathrm{C}$ ), followed by C8D $\beta$ plasma $\left(3.0 \times 10^{8}\right.$ cells in $1.5 \mathrm{ml}$ of gelatin-veronal buffer with $0.15 \mathrm{ml}$ of C8D $\beta$ plasma) for $30 \mathrm{~min}$ at $30^{\circ} \mathrm{C}$. Then, $0.2 \mathrm{ml}$ of the serially diluted test material was incubated $\left(37^{\circ} \mathrm{C}, 90 \mathrm{~min}\right)$ with $0.2 \mathrm{ml}$ C9 guinea pig ( $500 \mathrm{CH}_{50} \mathrm{U} / \mathrm{ml}$, Cordis Laboratories, Miami, Fl), $0.4 \mathrm{ml}$ of buffer, and $0.2 \mathrm{ml} \mathrm{EAC1-7}\left(1 \times 10^{8}\right.$ cells $\left./ \mathrm{ml}\right)$. After incubation, $2 \mathrm{ml}$ of $0.15 \mathrm{M} \mathrm{NaCl}$ was added, the tubes centrifuged $(1,800 \mathrm{rpm}, 10 \mathrm{~min}$, $0^{\circ} \mathrm{C}$ ) and lysis was determined by measuring absorbance of the supernatant at $415 \mathrm{~nm}$. For each dilution of test material, $z$ values were calculated from $z=-\ln (1-y)$, where $y$ is the percentage cell lysis (after correction for background lysis) as compared to $100 \%$ lysis with distilled water. Values of $z$ were plotted against test reagent dilutions and $1 \mathrm{CH}_{50}$ $\mathrm{U}$ determined from the dilution that gave $z=0.69$, equivalent to $50 \%$ lysis. The concentration of $\mathrm{C} 8$ activity in undiluted test reagent was then calculated. Normal titers were $185 \mathrm{CH}_{50} \mathrm{U} / \mathrm{ml}$ and $1.9 \times 10^{5} \mathrm{C} 8 \mathrm{U} / \mathrm{ml}$. Verapamil did not have any effect on hemolytic activity. 
Tissue processing for immunofluorescence (IF) and electron microscopy $(E M)$. Direct IF was performed on kidney tissue obtained at the end of perfusion and snap-frozen in dry ice-isopentane, sectioned at 4 $\mu \mathrm{m}$ in a cryostat and fixed in ether-ethanol, as previously described (22). All tissue was stained with fluoresceinated IgG fractions of monospecific antisera, including rabbit anti-sheep IgG, rabbit anti-guinea pig IgG and goat anti-human C3 (Cappel Laboratories, West Chester, PA). Even though guinea pig anti-sheep IgG cross-reacted with the fluoresceinated goat anti-human C3 in Ouchterlony double diffusion in agarose, this did not occur when the guinea pig anti-sheep IgG was tissue-bound.

For EM, kidneys were either perfusion-fixed with $1.25 \%$ glutaraldehyde in $0.1 \mathrm{M}$ sodium cacodylate buffer, $\mathrm{pH} 7.4$, or immersion-fixed in paraformaldehyde $(2.5 \mathrm{~g} / 100 \mathrm{ml})$-glutaraldehyde $(2.0 \mathrm{~g} / 100 \mathrm{ml})$ in $0.1 \mathrm{M}$ sodium cacodylate buffer, $\mathrm{pH} 7.4$, and further treated as previously described (6). At least three kidneys in each group were examined by IF, and two to four kidneys by EM.

Experimental design. Mediation of injury was studied in the first set of experiments, consisting of four groups of kidneys, listed in Table I. $3 \mathrm{~d}$ before kidney perfusion, rats in groups I, II, and IV received an intravenous, subnephritogenic dose of non C-fixing $\gamma 2$ sheep anti-rat Fx1A (12 mg of IgG fraction) that served as "planted" antigen (5). During the perfusion, all groups received $4.0 \mathrm{ml}$ of guinea pig anti-sheep IgG as HI whole serum, containing $35 \mathrm{mg}$ of antibody. The type of human plasma used is indicated in Table I. Thus, groups I and IV constitute the experimental kidneys, groups II and III being controls.

The second part of the study involved the quantitation of bound glomerular antigen and antibody to evaluate the effects of different perfusion conditions on antibody binding. Antigen was administered as above (8 mg of $\gamma 2$ anti-Fx1A, to which $4 \times 10^{6} \mathrm{cpm}$ of trace-labeled IgG was added). Plasma perfusions as for groups I, II, and IV were carried out (for $1 \mathrm{~h}$ ) with tracer antibody alone (30-60 $\mu \mathrm{g}$ of ${ }^{125} \mathrm{I}$-affinity purified guinea pig anti-sheep IgG).

Because the yield of purified C8 isolated from whole plasma is low (37), reconstitution of $\mathrm{C} 8$ activity in C8D plasma was performed by two alternate methods. In the first case, two kidneys with planted antigen (as in groups I, II, and IV) were perfused with $50 \% \mathrm{C} 8 \mathrm{D} \beta$ plasma and 4.0 $\mathrm{ml}$ of fresh guinea pig antiserum (C8R, Table I), as opposed to $\mathrm{HI}$ antiserum used in groups I-IV. Fresh guinea pig antiserum provided 35 mg of anti-sheep IgG, as well as sufficient $\mathrm{C} 8$ to reconstitute the $\mathrm{CH}_{50}$ of C8D plasma. Two control kidneys with planted antigen were perfused with $4.0 \mathrm{ml}$ of fresh guinea pig anti-sheep IgG without added human plasma (GPS, Table I). Secondly, enough C8D $\alpha-\gamma$ serum was available to perform one perfusion with $\mathrm{HI}$ antiserum and a mixture of $\mathrm{C} 8 \mathrm{D} \beta$ plasma and $\mathrm{C} 8 \mathrm{D} \alpha-\gamma$ serum ( $25 \mathrm{ml}$ each). Whereas the individual reagents have no hemolytic or $\mathrm{C8}$ activity, when combined the $\mathrm{CH}_{50}$ and $\mathrm{C8}$ activity are both reconstituted (Table I).

Statistics. Parametric data, including RVR, $\mathrm{C}_{\text {inulin }}$, and $\mathrm{FR}_{\mathbf{N a}}$, were analyzed by one-way analysis of variance (38) at each time period. Where a significant difference was found, meaningful individual comparisons were made between groups utilizing Scheffe's analysis (38). Nonparametric data (protein excretion, antibody deposition) were analyzed by the Kruskal-Wallis analysis of variance (39), and where significant differences occurred, these were then examined by the Mann-Whitney $U$ test (39).

\section{Results}

Hemolytic activity. Fresh-frozen plasma when thawed, pooled, heparinized, and dialyzed contained $90-100 \% \mathrm{CH}_{50}$ of fresh human serum. After the addition of fresh plasma to BSA-KHB ( $50 \% \mathrm{vol} / \mathrm{vol}$ ), the $\mathrm{CH}_{50}$ of the mixture was $50 \%$ of normal (Table I). This declined by $25 \%$ at $60 \mathrm{~min}$ of perfusion (i.e., to $37.5 \%$ of normal) and a further $25 \%$ by $90 \mathrm{~min}$ (to $25 \%$ of normal). $\mathrm{HI}$ plasma, $\mathrm{C} 8 \mathrm{D}$ plasma, and $\mathrm{HI}$ antisera had no detectable hemolytic activity. The $\mathrm{CH}_{50}$ and $\mathrm{C} 8$ titers of the perfusates in all experimental groups are given in Table $\mathrm{I}$.

Protein excretion and function of IPKs. Protein excretion is demonstrated in Fig. 1. The lowest values were found in control groups (II and III), levels that are comparable to those previously described in "normal" IPKs perfused with BSA (24, 26, 40-42). Kidneys in group III had a slightly higher protein excretion than group II, which reached statistical significance after $20 \mathrm{~min}$. Antibody binding in the presence of C (group I) markedly enhanced protein excretion. This increase became significant after $20 \mathrm{~min}$ and, by the end of the $2 \mathrm{~h}$, the majority of group I kidneys were massively proteinuric (Fig. 1). Substitution of fresh normal plasma with fresh C8D $\beta$ plasma (group IV) resulted in only baseline levels of protein excretion that were comparable to control groups (Fig. 1).

Functional data for the experimental groups (I and IV) and controls (II and III) is presented in Table II. RVR was not significantly different between the groups at any time point, except period 6, where it was lower in group II. Among the two control

Table I. Characteristics of Isolated Perfused Kidneys, Perfusate Composition, and Complement Activity

\begin{tabular}{|c|c|c|c|c|c|}
\hline \multirow[b]{2}{*}{ Group } & \multirow{2}{*}{$\begin{array}{l}\text { Planted antigen: } \\
\text { sheep anti-Fx } 1 A^{*}\end{array}$} & \multicolumn{2}{|c|}{ Perfusate composition $\ddagger$} & \multicolumn{2}{|c|}{$\mathrm{C}$ activity of perfusate $\S$} \\
\hline & & Anti-sheep IgG & Human plasma & $\mathrm{CH}_{\text {so }}$ & C8 titer \\
\hline & & & & \% normal & \% normal \\
\hline I (8) & + & HI & fresh normal & 50 & 50 \\
\hline II (6) & + & HI & HI normal & 0 & not done \\
\hline III (6) & - & HI & fresh normal & 50 & 50 \\
\hline IV (5) & + & HI & $\mathrm{C} 8 \mathrm{D} \beta$ & 0 & 0 \\
\hline \multicolumn{6}{|l|}{ C8 Replacement } \\
\hline C8R (2) & + & fresh & $\operatorname{C8D} \beta$ & 80 & 15 \\
\hline GPS (2) & + & fresh & - & 25 & 15 \\
\hline $\operatorname{C8D} \beta+\alpha-\gamma(1)$ & + & HI & $\mathrm{C} 8 \mathrm{D} \beta+\mathrm{C} 8 \mathrm{D} \alpha-\gamma$ & 50 & 20 \\
\hline
\end{tabular}

\footnotetext{
* $12 \mathrm{mg}$ of IgG given intravenously to rats $3 \mathrm{~d}$ before kidney perfusion. $\ddagger 50 \%$ human plasma (vol/vol) in BSA-KHB (100 ml), to which $4.0 \mathrm{ml}$ of fresh or heat-inactivated (HI) guinea pig anti-sheep IgG was added. $\S \mathrm{CH}_{50}$ and $\mathrm{C} 8$ titer of the final perfusate is expressed as a percentage of the activity in undiluted, fresh, normal human serum. "Number of kidneys studied is in parentheses.
} 


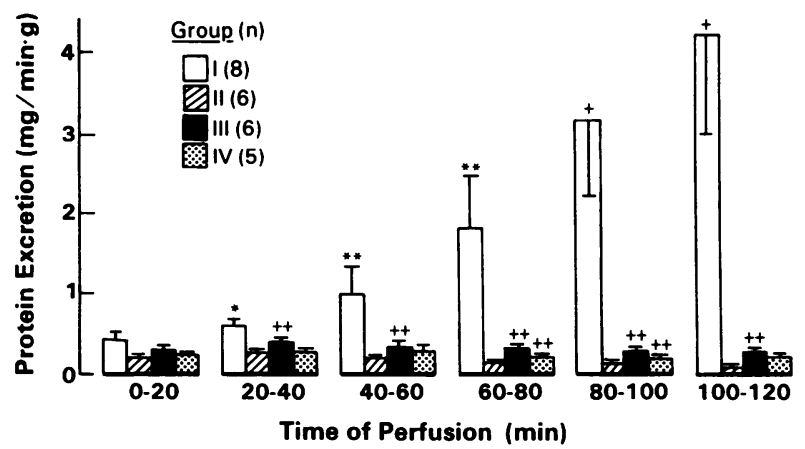

Figure 1. Protein excretion of IPKs. Greatest protein excretion is seen in antigen-containing kidneys, perfused with antibody and fresh plasma (group I). Normal kidneys perfused with antibody and fresh plasma (group III) and antigen-containing kidneys perfused with antibody and $\mathrm{HI}$ (group II) or C8D (group IV) plasma displayed baseline proteinuria, although kidneys perfused with fresh plasma (groups III and IV) excreted slightly more protein than group II. Data are presented as the mean \pm SEM. The number of kidneys studied $(n)$ is shown in the figure. A significant difference between the four groups was present after 20 min (Kruskal-Wallis one-way analysis of variance). Differences between the groups (Mann-Whitney $U$ test) are as follows: group I vs. II, III, and IV $P<0.04^{*}, P<0.025^{* *}, P$ $<0.002^{+}$; group II vs. III and II vs. IV $P<0.04^{++}$.

groups, $\mathrm{HI}$ plasma (group II) resulted in higher $\mathrm{C}_{\text {inulin }}$ and $\mathrm{FR}_{\mathrm{Na}}$ than group III, and these were also higher than in groups I and IV (significant during periods 2-4 and 2-6, respectively). Experimental kidneys (group I) showed a lower $F_{R_{\mathrm{Na}}}$ than controls and the C8D group (significant during periods 1 and 4-6). Thus, except for $\mathrm{FR}_{\mathrm{Na}}$, immunologic reaction in the presence of fresh plasma did not substantially alter kidney function in this model.

Quantitation of antigen and antibody. The purpose of these experiments was twofold: $(a)$ to determine the variability between kidneys in bound antigen, resulting from an identical intravenous dose of anti-Fx IA, and $(b)$ to establish whether the type of plasma influenced antibody binding when perfused under identical conditions. The RVR and $\mathrm{C}_{\text {inulin }}$ of kidneys containing planted antigen and perfused with tracer amounts of antibody (data not shown) were similar to those seen in the experiments with the full dose of antibody (groups I, II, and IV, above). The sole exception occurred with fresh plasma perfusions, where RVR was higher with the tracer dose as compared to the full dose of antibody. This resulted in a 2.5-fold higher filtration fraction for trace-dose perfusions, which is still trivial compared to in vivo values ( $\sim 4 \%$ vs. $20 \%)$. It is unlikely that this difference in filtration fraction significantly altered binding; if anything, it could have potentially produced exaggerated values in the tracer group (43). Thus, it is felt that the findings of tracer antibody perfusions are representative of experiments using the full antibody dose.

Whether expressed as the absolute amount of guinea pig IgG bound (microgram/38,000 glomeruli adjusted to a perfusate concentration of $0.33 \mu \mathrm{g}$ guinea pig $\mathrm{IgG} / \mathrm{ml}$ ) or as a function of the amount of planted antigen in each kidney (guinea pig IgG/ sheep IgG), no detectable difference was found between the three groups (Table III). Thus the difference in protein excretion observed with different types of plasma could not be attributed to alterations in glomerular antibody deposition.

Replacement of $\mathrm{C} 8$. Two methods of $\mathrm{C} 8$ reconstitution were employed. First, fresh guinea pig anti-sheep IgG (rather than HI antiserum as in groups I-IV) was used as a source of C8. When added to perfusate that contained $50 \%$ C8D $\beta$ plasma (group C8R, Table I) it fully reconstituted the $\mathrm{CH}_{50}$, provided $15 \%$ of normal $\mathrm{C} 8$ activity, and restored the high level of protein excretion (Fig. 2) seen in group I kidneys (Fig. 1). It is likely that the earlier appearance and greater magnitude of proteinuria in group C8R (than group I) is a result of the relatively higher final

Table II. Function of Isolated Perfused Kidneys

\begin{tabular}{|c|c|c|c|c|c|c|c|}
\hline \multicolumn{2}{|c|}{$\begin{array}{l}\text { Period } \\
\text { Time (min) }\end{array}$} & $\begin{array}{l}1 \\
0-20\end{array}$ & $\begin{array}{l}2 \\
20-40\end{array}$ & $\begin{array}{l}3 \\
40-60\end{array}$ & $\begin{array}{l}4 \\
60-80\end{array}$ & $\begin{array}{l}5 \\
80-100\end{array}$ & $\begin{array}{l}6 \\
100-120\end{array}$ \\
\hline \multicolumn{8}{|c|}{ Group } \\
\hline \multirow[t]{3}{*}{ I } & $\mathbf{R V R}^{*}$ & $4.72 \pm 0.98$ & $4.66 \pm 1.03$ & $4.61 \pm 0.95$ & $4.87 \pm 0.87$ & $5.62 \pm 1.03$ & $6.81 \pm 1.45$ \\
\hline & $C_{\text {inulinf }}$ & $0.16 \pm 0.24$ & $0.35 \pm 0.16^{\prime \prime \prime}$ & $0.49 \pm 0.32$ & $0.38 \pm 0.11$ & $0.36 \pm 0.12$ & $0.37 \pm 0.22$ \\
\hline & $\mathrm{FR}_{\mathrm{Na}} \S$ & $89.5 \pm 6.2 \S \S$ & $95.3 \pm 2.1$ & $94.8 \pm 2.1$ & $90.3 \pm 6.5 \S \S$ & $82.4 \pm 9.5^{\prime \prime \prime \prime}$ & $74.4 \pm 13.5^{1111}$ \\
\hline \multirow[t]{3}{*}{ II } & RVR & $4.22 \pm 0.69$ & $3.83 \pm 0.74$ & $3.67 \pm 0.77$ & $3.66 \pm 0.89$ & $3.68 \pm 0.93$ & $3.61 \pm 0.88 \pi$ \\
\hline & $C_{\text {inulin }}$ & $0.37 \pm 0.30$ & $0.86 \pm 0.15+\dagger$ & $0.86 \pm 0.06^{* *}$ & $0.69 \pm 0.23^{\prime \prime}$ & $0.49 \pm 0.20$ & $0.35 \pm 0.20$ \\
\hline & $\mathrm{FR}_{\mathrm{Na}}$ & $98.4 \pm 0.6$ & $98.7 \pm 1.13$ & $98.5 \pm 1.2 \dagger \dagger$ & $98.6 \pm 0.7+\dagger$ & $98.1 \pm 1.6^{\prime \prime}$ & $97.9 \pm 2.1^{11}$ \\
\hline & RVR & $5.21 \pm 1.04$ & $5.23 \pm 1.33$ & $5.17 \pm 1.48$ & $5.59 \pm 1.97$ & $5.99 \pm 2.34$ & $6.74 \pm 2.82$ \\
\hline & $\mathrm{C}_{\text {inulin }}$ & $0.13 \pm 0.08$ & $0.50 \pm 0.19$ & $0.43 \pm 0.14$ & $0.52 \pm 0.18$ & $0.42 \pm 0.10$ & $0.38 \pm 0.11$ \\
\hline & $\mathrm{FR}_{\mathbf{N a}}$ & $91.9 \pm 6.2$ & $97.3 \pm 1.2$ & $95.5 \pm 2.1$ & $94.7 \pm 3.1$ & $93.4 \pm 3.5$ & $91.7 \pm 4.1$ \\
\hline \multirow[t]{3}{*}{ IV } & RVR & $4.40 \pm 0.75$ & $4.05 \pm 0.69$ & $4.16 \pm 0.67$ & $4.29 \pm 0.54$ & $4.56 \pm 0.43$ & $4.93 \pm 0.53$ \\
\hline & $\mathrm{C}_{\text {inulin }}$ & $0.67 \pm 0.18$ & $0.73 \pm 0.07$ & $0.64 \pm 0.10$ & $0.52 \pm 0.06$ & $0.48 \pm 0.03$ & $0.44 \pm 0.11$ \\
\hline & $\mathrm{FR}_{\mathrm{Na}}$ & $97.2 \pm 0.9$ & $95.3 \pm 1.1$ & $95.1 \pm 0.8$ & $95.3 \pm 1.2$ & $94.4 \pm 2.5$ & $93.5 \pm 2.0$ \\
\hline
\end{tabular}

All values are expressed as mean \pm SD. $\quad{ }^{*} \mathrm{RVR}$, renal vascular resistance $(\mathrm{mmHg} \cdot \mathrm{g} \cdot \mathrm{min} / \mathrm{ml}) . \quad \ddagger \mathrm{C}_{\mathrm{inulin}}$, inulin clearance $(\mathrm{ml} / \mathrm{min} \cdot \mathrm{g})$. $\S \mathrm{FR}$, fractional reabsorption of sodium (\%). " $P<0.05$. I $P<0.025$. ${ }^{* *} P<0.01$. $\quad \dagger \dagger P<0.005$, II vs. I, III, and IV. $\$ \S P<0.05$. "II" $P<0.005$, I vs. II, III, and IV. 
Table III. Quantitation of Antigen and Antibody Deposition in Glomeruli

\begin{tabular}{llll}
\hline $\begin{array}{l}\text { Plasma } \\
\text { perfusate } \\
(n)^{*}\end{array}$ & $\begin{array}{l}\text { Antibody: Guinea } \\
\text { pig anti-sheep IgG }\end{array}$ & $\begin{array}{l}\text { Antigen: Sheep } \\
\text { anti-Fx1A }\end{array}$ & $\frac{\text { Antibody }}{\text { Antigen }} \times 10^{3}$ \\
\hline & $\mu g / 38,000$ glomeruli & $\mu g / 38,000$ glomeruli & \\
Fresh (4) & $0.32 \pm 0.05$ & $14.9 \pm 2.4$ & $22.2 \pm 0.5$ \\
& $(0.26-0.38)$ & $(11.6-17.1)$ & $(17.8-29.2)$ \\
HI (5) & $0.28 \pm 0.14$ & $16.1 \pm 5.7$ & $20.8 \pm 13.3$ \\
& $(0.12-0.40)$ & $(9.9-23.0)$ & $(5.8-33.4)$ \\
C8D $\beta(4)$ & $0.26 \pm 0.03$ & $14.5 \pm 1.6$ & $18.6 \pm 3.7$ \\
& $(0.23-0.30)$ & $(12.9-16.6)$ & $(14.1-21.7)$ \\
\hline
\end{tabular}

All values are expressed as mean $\pm \mathrm{SD}$ with range in parentheses below. There are no significant differences between the three groups in any variable. * Number of kidneys studied is in parentheses.

$\mathrm{CH}_{50}$ of this perfusate (Table I). The enhanced protein excretion was not due to an independent effect of fresh guinea pig antiserum because antiserum added alone to plasma-free perfusate (group GPS, Table I and Fig. 2) produced baseline proteinuria.

Replacement of $\mathrm{C} 8$ was also accomplished by combining two complementary $\mathrm{C} 8 \mathrm{D}$ reagents that independently do not have hemolytic or $\mathrm{C} 8$ activity (i.e., C8D $\beta$ plasma and C8D $\alpha$ $\gamma$ serum). When $25 \% \mathrm{vol} / \mathrm{vol}$ of each was added to the perfusate, the $\mathrm{CH}_{50}$ was reconstituted to $50 \%$ of normal and the $\mathrm{C} 8$ titer to $20 \%$ (Table I). Perfusate with reconstituted C8 activity produced enhanced proteinuria (Fig. 2) that was unequivocally higher than C8D $\beta$ perfusions (group IV, Figs. 1 and 2 ) and was in the range of group I kidneys.

IF and EM findings. Antigen-containing kidneys perfused with guinea pig anti-sheep IgG (groups I, II, and IV) demonstrated positive IF staining of the glomerular capillary wall for

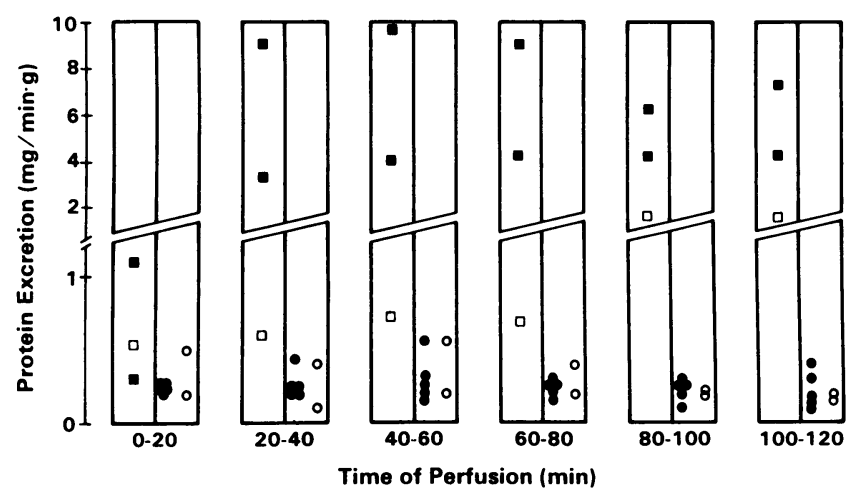

Figure 2. Replacement of C8. All kidneys contained planted antigen, and were perfused with guinea pig anti-sheep IgG. Protein excretion was markedly enhanced to levels comparable with group I when C8 activity was reconstituted in C8D $\beta$ plasma perfusate with fresh guinea pig antiserum $(C 8 R, \square)$ (see text for details). Control perfusions with fresh guinea pig antiserum added to plasma-free perfusate (GPS, 0 ) resulted only in baseline proteinuria which is similar to that of perfusions containing no $\mathrm{C} 8$ activity, i.e., $\mathrm{HI}$ guinea pig antiserum and C8D $\beta$ plasma (group IV, $\bullet$ ). Perfusion with HI antiserum plus the combination of C8D $\beta$ plasma and C8D $\alpha-\gamma$ serum also induced enhanced protein excretion (ㅁ). sheep IgG and guinea pig IgG (Fig. $3 a$ and $b$ ) in a granular pattern. No difference in intensity was detected between the groups. Positive $\mathrm{C} 3$ staining of similar intensity and distribution was seen in kidneys perfused with fresh normal plasma (group I) (Fig. $3 c$ ) and C8D plasma (group IV). There was also some C3 staining of vessel walls. No staining for C3 was visible in group II kidneys perfused with $\mathrm{HI}$ plasma (Fig. $3 d$ ), and no glomerular staining for any component was present in group III kidneys that contained no planted antigen.

Except for rare damage to endothelial cells, EM of group III controls without planted sheep anti-Fx1A (Fig. 4) demonstrated good preservation of glomerular architecture after $2 \mathrm{~h}$ of perfusion. Subepithelial electron dense deposits were present in all glomeruli from animals injected with sheep anti-Fx 1A (groups I, II, and IV). Kidneys perfused with HI (II) or C8D (IV) plasma showed well-preserved glomerular epithelial cells, with only minimal focal effacement of podocytes overlying larger electron dense deposits (Fig. 5). In contrast, heavily proteinuric kidneys in groups I and C8R showed diffuse epithelial cell changes (Fig. 6) characterized by massive effacement and simplification of foot processes, microvillous degeneration, vacuolization of the cell body, and focal retraction with complete denudation of the GBM. In such areas electron-dense deposits often persisted, together with small, membrane-bound vesicles (Fig. $6 b$ and $c$ ) attached to the surface of the GBM facing the urinary space. Occasionally, capillary loops completely devoid of an epithelial cell layer could be observed in heavily proteinuric kidneys (Fig. 7). Signs of overt epithelial cell necrosis were invariably seen in association with this latter finding. These observations indicate that marked epithelial cell injury occurs near the site of antibody deposition only when conditions are suitable for assembly of the MAC.

\section{Discussion}

This study establishes, for the first time, that C8 can mediate injury in an intact organ system through assembly of the cytopathic MAC. Utilizing a cell-free, plasma-perfused isolated rat kidney model, we demonstrated that enhanced glomerular permeability, induced by subepithelial in situ immune complex formation, is dependent on the presence of $\mathrm{C} 8$. These conclusions are supported by the following results. Marked proteinuria was observed in antigen-containing kidneys perfused with C-fixing antibody and fresh plasma. No increment in protein excretion occurred when normal (antigen-free) kidneys were perfused with antibody and fresh plasma or antigen-containing kidneys were perfused with antibody and HI or C8D plasma. Severe proteinuria developed when total $\mathrm{C}$ activity was restored to $\mathrm{C} 8 \mathrm{D}$ plasma by reconstitution with $\mathrm{C} 8$. Furthermore, the absence of injury in kidneys perfused with $\mathrm{HI}$ and $\mathrm{C} 8 \mathrm{D}$ plasma could not be accounted for by qualitative and quantitative differences in glomerular deposits of antigen or antibody as compared to kidneys perfused with fresh plasma. Because C8 is essential for C-mediated membranolysis and has no other defined role, it is reasonable to conclude that injury in rat $\mathrm{MN}$ is mediated by the MAC.

From these studies it seems most likely that proteinuria in rat $\mathrm{MN}$ is the result of a structural or compositional alteration in the glomerular capillary wall. No consistent hemodynamic change was observed that could account for the time-related progressive increase in proteinuria in kidneys perfused with an- 

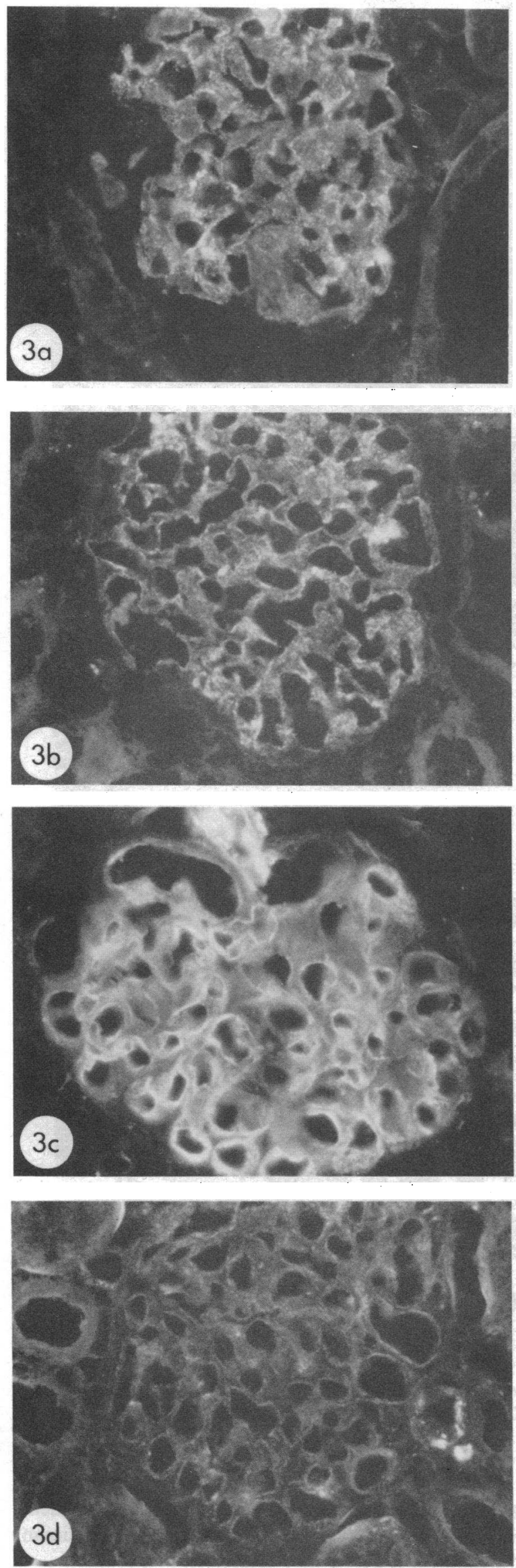

tibody and a complete source of $\mathrm{C}$. In contrast, ultrastructural observations in these experiments suggest that antibody-directed, $\mathrm{C}$-induced injury is directed at the glomerular visceral epithelial cells. Foot process effacement, separation of podocytes from the GBM, and formation of membrane-bound vesicles were clearly related to the presence of $\mathrm{C}$ hemolytic activity in the perfusate and the development of massive proteinuria. These changes have not been seen in IPKs made proteinuric by other $\mathrm{C}$-independent means $(25,26)$ indicating that they are unlikely to be nonspecific effects of proteinuria.

The probability of $\mathrm{C}$-induced injury to the epithelial cell membrane in rat $\mathrm{MN}$ is consistent with the morphologic evidence of epithelial cell injury discussed above, with the known membranolytic action of the MAC, and with the location of electron-dense deposits in this lesion. Immunohistologic studies of rat serum sickness indicate that immune deposits produced by antibody reacting with exogenous antigen in the subepithelial space induces MAC assembly in the epithelial plasma membrane (14). It is probable that the MAC is similarly located in Heymann nephritis, where formation of subepithelial immune deposits is likely due to antibody-modulated capping and shedding of endogenous epithelial cell antigens $(44,45)$. Furthermore, as the MAC requires a phospholipid layer for insertion, the GBM is an unlikely target for the MAC because it does not normally contain phospholipids (46). Assembly of the MAC in the epithelial cell plasma membrane is also in keeping with current knowledge of its membranolytic action. This involves the formation of transmembrane channels (47) and rearrangement and/ or loss of phospholipids $(48,49)$ with subsequent loss of cell membrane integrity. In contrast to C-dependent erythrocyte lysis that is an all-or-nothing "one-hit" phenomenon (47), lysis of several types of nucleated cells appears to require the formation of multiple transmembrane channels (1). The absence of total lysis of epithelial cells in experimental $\mathrm{MN}$ is compatible with established sublytic cytopathic effects of the terminal C pathway on nucleated cells, which involve the release of intracellular contents (1), including reactive oxygen species (50) and prostaglandins $(2,3,51)$. Further investigation is necessary to determine the precise location of the MAC and whether altered glomerular permeability in experimental $\mathrm{MN}$ is the direct effect of epithelial cell injury leading to focal sieving defects or an indirect consequence of the release of other mediators of basement membrane or cellular injury.

One might speculate as to why these florid epithelial cell alterations are not routinely seen in vivo in experimental or human MN. In the IPK model described here immunopathologic changes that develop over several days in PHN $(5,35)$, weeks in active Heymann nephritis (52), and months or years in human $\mathrm{MN}$, are condensed into a period of $2 \mathrm{~h}$. During this time an amplified immunologic attack is directed at the glomerulus that may have little opportunity or capacity to regenerate and repair epithelial cell damage and clear the debris. This explanation implies that the findings in the IPK are an exaggeration and acceleration of a process that occurs in vivo but is not usually

Figure 3. Immunofluorescence microscopy of representative glomeruli. Antigen-containing kidneys perfused with antibody and fresh plasma (group I) or C8D plasma (group IV) showed glomerular capillary wall staining for sheep IgG, guinea pig IgG, and rat C3 (as in panels $a, b$, and $c$ respectively), whereas such kidneys were negative for rat C3 when perfused with HI plasma (group II) (as in panel $d)(\times 360)$. 


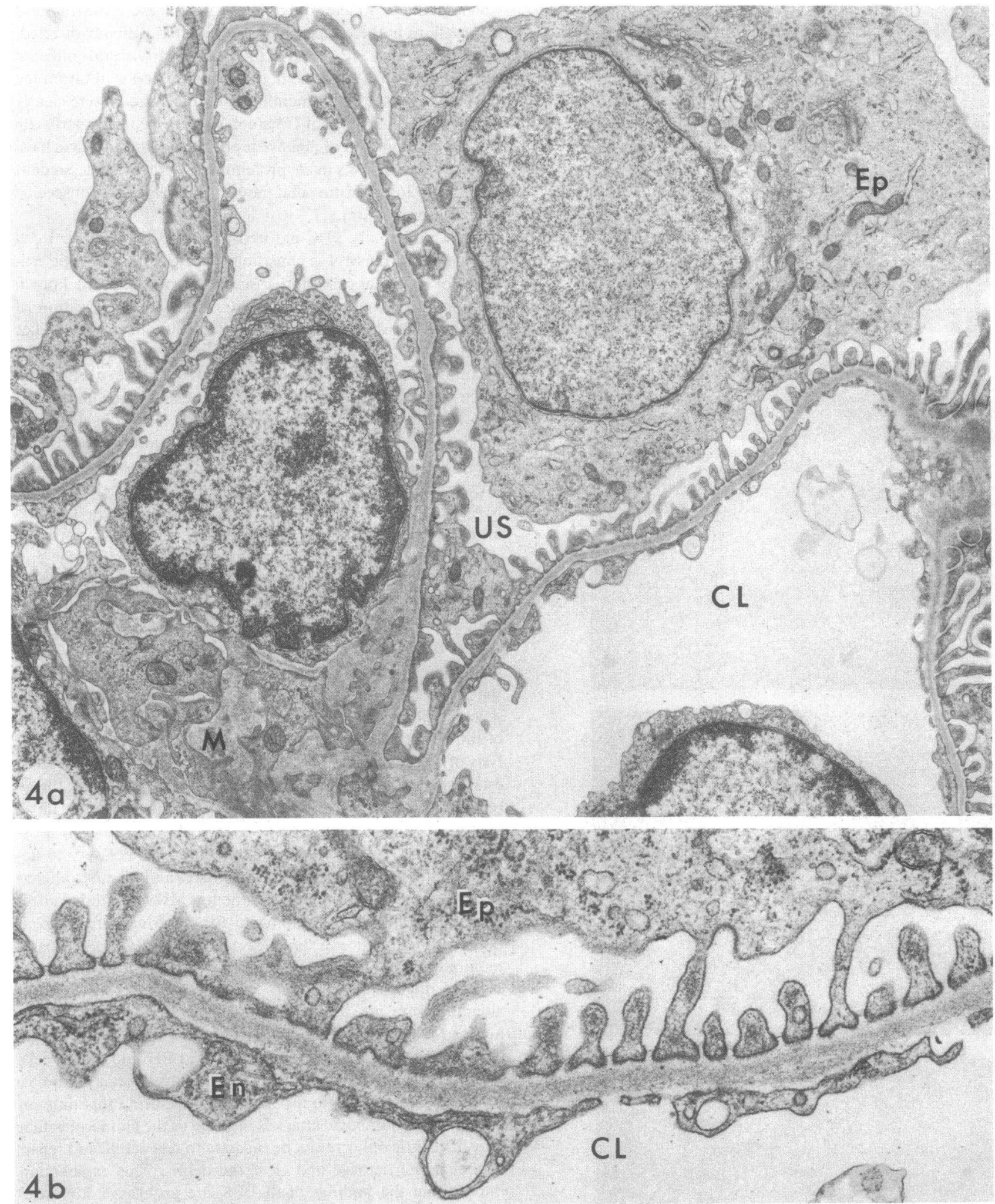

Figure 4. Ultrastructure of group III kidneys. (a) Two intact capillary loops with adjoining mesangium (M) are depicted $(\times 11,250)$. (b) Details of the glomerular capillary wall. Electron-dense deposits are absent $(\times 35,000)$. Ep, glomerular epithelial cells; US, urinary space; CL, capillary lumen; En, endothelium.

visible. Actually, published observations suggest the possibility of epithelial injury in the Heymann models of rat MN $(53,54)$. In addition, vesicular bodies resembling those seen in this study and possibly representing membrane fragments have been identified within subepithelial electron densities in cases of human MN (55). 


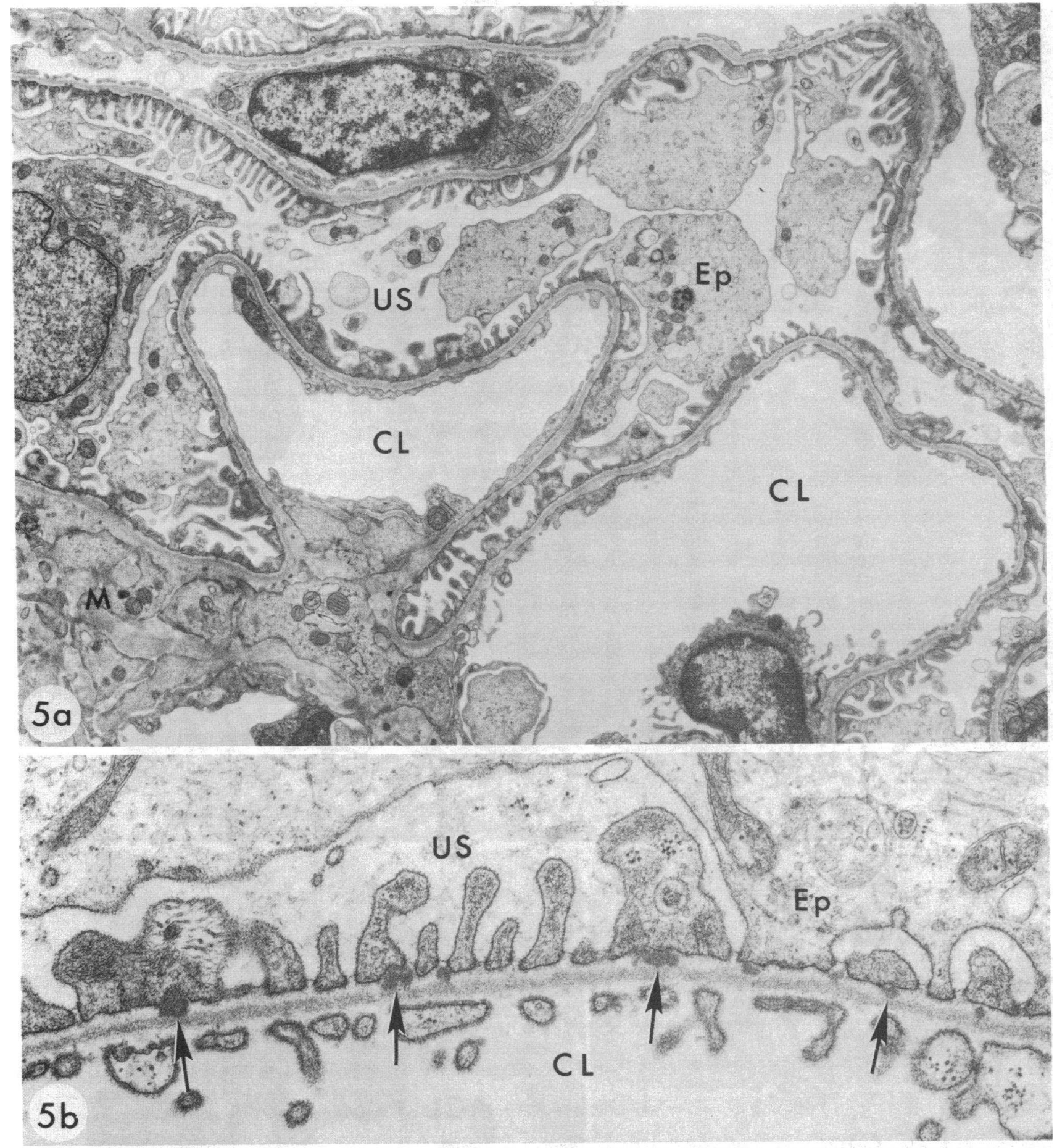

Figure 5. Ultrastructure of groups II and IV kidneys. (a) The general architecture of the glomerulus is well preserved, with minimal, focal obliteration of foot processes (group II kidney) $(\times 8,400)$. (b) Glomerular capillary wall of group IV kidney. Small, discrete electron-dense

Although the plasma-perfused IPK proved invaluable in defining the role of $\mathrm{C} 8$ in rat $\mathrm{MN}$, one needs to recognize certain potential limitations of the model. First, $\mathrm{C}_{\text {inulin }}$ and sodium reabsorption in the IPK are subnormal as compared to normal kidneys in vivo and function declines further with time (41). Nevertheless, in our plasma-perfused kidneys, it was possible to deposits (arrows) are present in the subepithelial space. Notice preservation of the diaphragms in numerous epithelial slits, separating adjacent processes $(\times 35,000)$. Ep, glomerular epithelial cells; US, urinary space; $C L$, capillary lumen; $M$, mesangium.

achieve adequate and relatively stable function for $2 \mathrm{~h}$, with preservation of normal glomerular histology. $\mathrm{C}_{\text {inutin }}$ and sodium reabsorption compared favorably with IPKs perfused with plasma-free perfusates of similar oncotic pressure (41) even though vascular resistance was somewhat elevated and perfusion flow rate proportionately reduced, especially in the presence of 


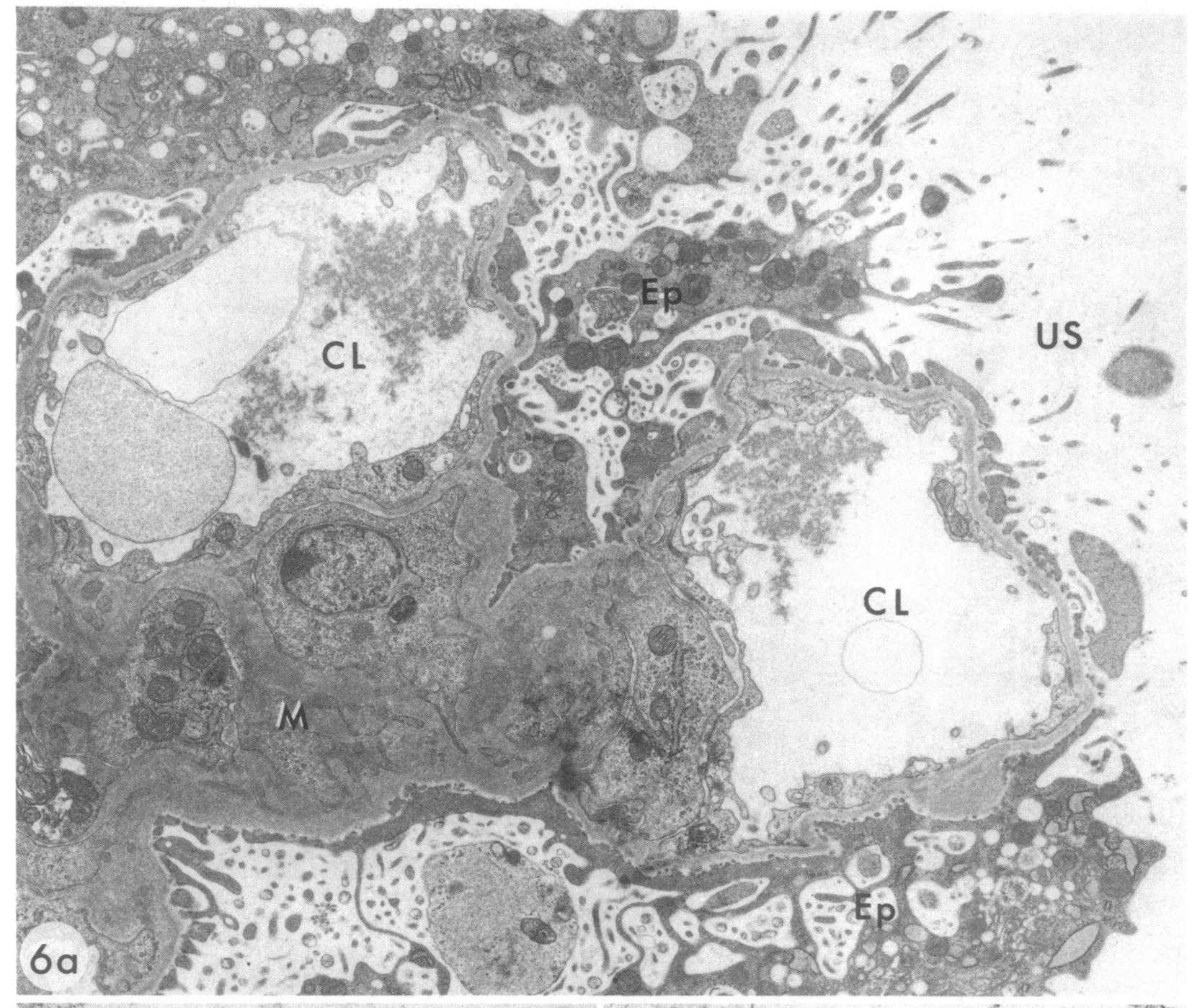

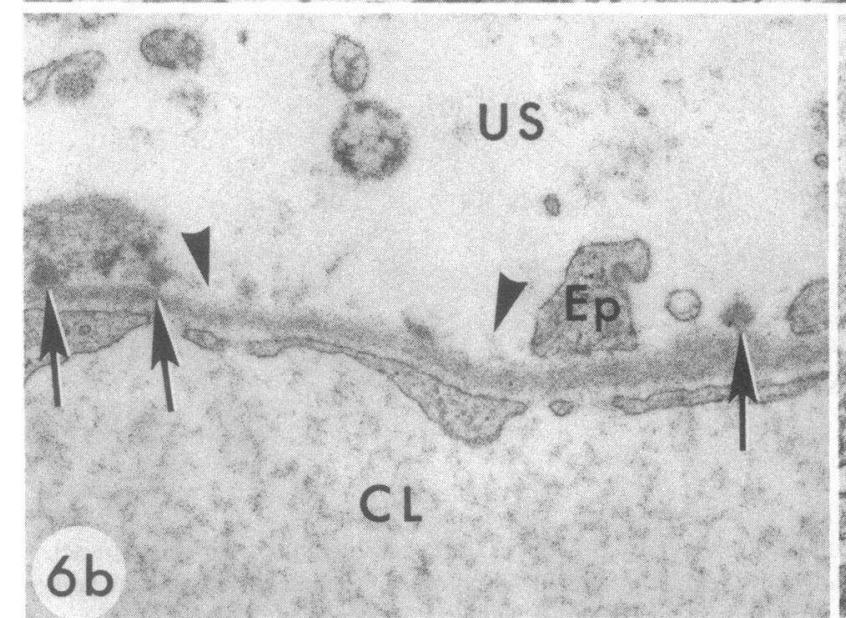

Figure 6. Ultrastructure of kidneys from groups I and C8R. (a) Glomerular capillary loop showing striking epithelial cell abnormalities, with massive effacement of interdigitating foot processes, microvillous transformation and vacuolization $(\times 11,250)$. (b) Details of the glomerular capillary wall, showing complete denudation of the basement membrane (arrowheads). Notice also the presence of electron-dense

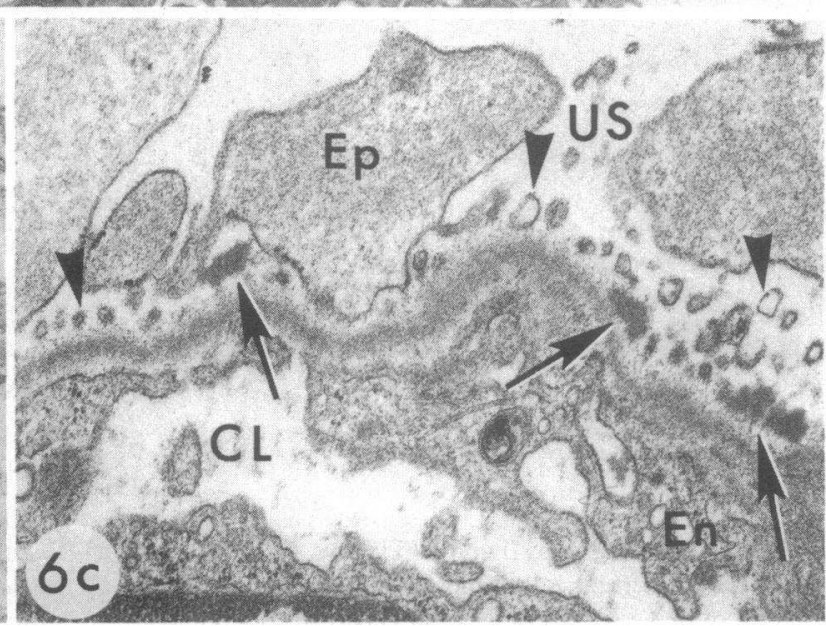

deposits on the epithelial side of the basement membrane (arrows) $(\times 25,000)$. (c) Retraction of epithelial cells and formation of small, membrane-bound vesicles (arrowheads) in a C8R kidney; electrondense deposits (arrows) are present in the lamina rara externa $(\times 24,500)$. Ep, epithelial cell; US, urinary space; $C L$, capillary lumen; $M$, mesangium, En, endothelium. 


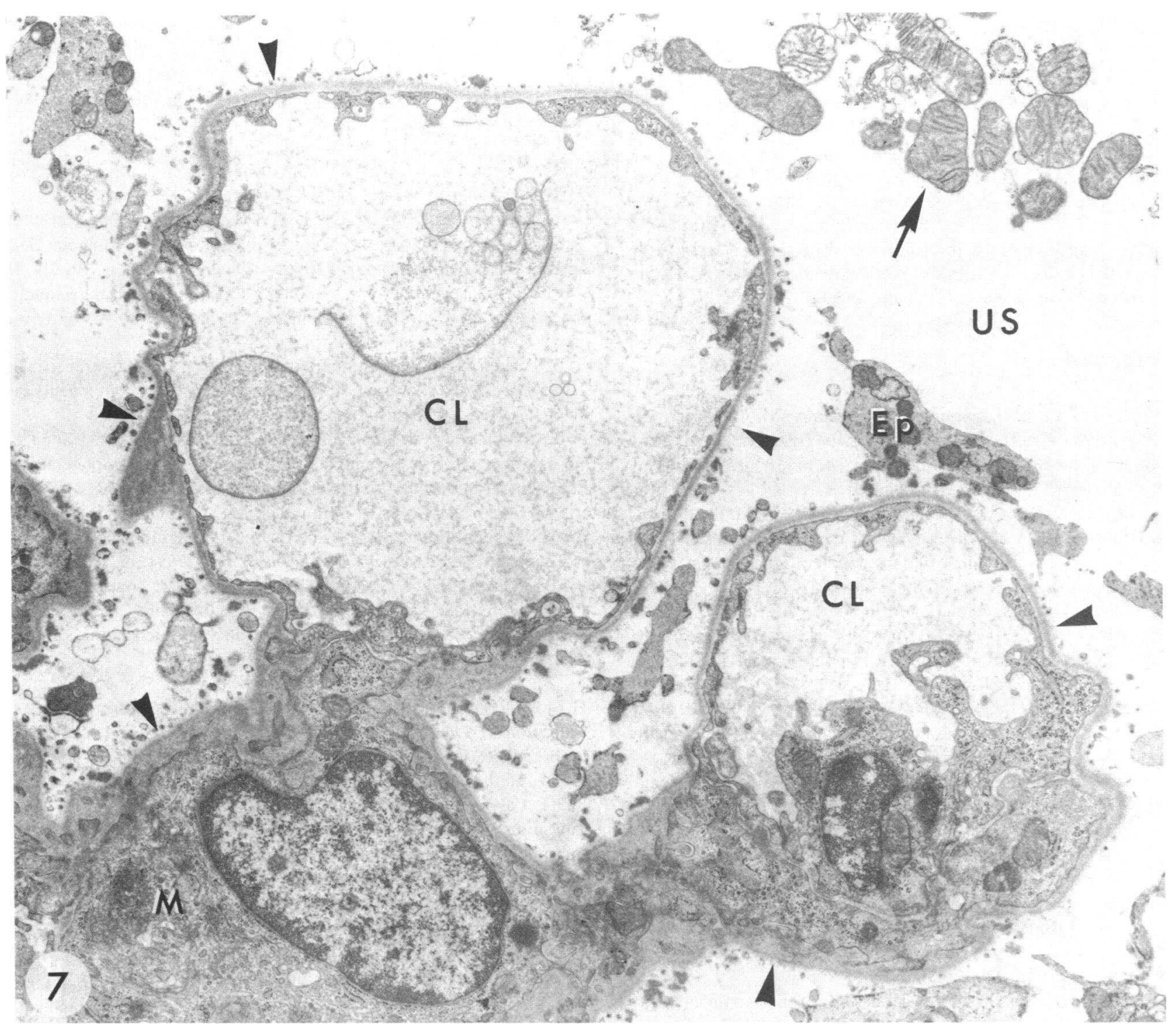

Figure 7. Ultrastructure of group I kidneys. Two capillary loops are completely devoid of glomerular epithelial cell layer. Notice the numerous small membrane-bound vesicles attached to the basement membrane (arrowheads). Loose cell organelles in the urinary space

fresh plasma (Table II). This vasoconstriction is at least partly due to angiotensin II generation upon addition of plasma angiotensinogen in the presence of high concentrations of renin (56). It was largely countered by the addition of verapamil in doses that did not independently affect proteinuria or $C_{\text {inulin }}$ in studies reported by others (24). Another potential disadvantage to the IPK is the high basal excretory rate of protein $(24,26$, $40-42)$. A substantial proportion of this proteinuria is of glomerular origin (24) even though glomerular ultrastructure is normal (25). Despite this basal proteinuria we were readily able to detect an alteration in glomerular permeability in experimental kidneys perfused with fresh plasma as early as $20 \mathrm{~min}$ after the addition of antibody.

In addition to our own observations in rat $\mathrm{MN}$, there now exists a substantial body of information suggesting that $\mathrm{C}$ components may directly contribute to cell injury and induce various (arrow) are indicative of cell disintegration and necrosis $(\times 11,250)$. Ep, epithelial cell; US, urinary space; CL, capillary lumen; M, mesangium.

forms of tissue damage witk:out invoking the cooperation of classical inflammatory cells. For instance, experimental hyperacute cardiac allograft rejection is $\mathrm{C}$-mediated but cell-independent $(57,58)$. C6 deficiency partly protects rabbits from cardiac xenograft rejection (59) and heterologous anti-GBM nephritis (60), antibody-directed bone resorption is indirectly mediated by terminal $\mathrm{C}$ components (51) and $\mathrm{C}$ exacerbates proteinuria when rat kidneys are perfused in vitro with anti-GBM antibody in the absence of cells (27). Thus, this study not only provides compelling functional and structural evidence that the MAC is responsible for proteinuria in a model that closely resembles a common form of chronic renal disease in man, it also lends strong support to the notion that the MAC may be responsible for tissue injury in several other clinical and experimental settings. To the best of our knowledge, it is also the first study to indicate that the MAC is responsible for epithelial cell injury. 


\section{Acknowledgments}

We wish to thank Ms. Deborah Sandstrom for expert technical help and Drs. Peter Rice (Boston City Hospital) and Bruce Petersen (Eli Lilly and Company) for assistance in obtaining C8-deficient plasma. We thank Mrs. Betty Kinsella for her expert typing.

This work was supported by research grants AM-30932 and AM35931 and training grant AM-07053 from the United States Public Health Service and Biomedical General Research Support Grant (RR-05487). Dr. Salant is an Established Investigator of the American Heart Association. Dr. Cybulsky is a fellow of the Kidney Foundation of Canada and Fonds de la Recherche en Santé du Québec.

\section{References}

1. Koski, C. L., L. E. Ramm, C. H. Hammer, M. M. Mayer, and M. L. Shin. 1983. Cytolysis of nucleated cells by complement: cell death displays multi-hit characteristics. Proc. Nat. Acad. Sci. USA. 80:38163820.

2. Imagawa, D. K., N. E. Osifchin, W. A. Paznekas, M. L. Shin, and M. M. Mayer. 1983. Consequences of cell membrane attack by complement: release of arachidonate and formation of inflammatory derivatives. Proc. Nat. Acad. Sci. USA. 80:6647-6651.

3. Hansch, G. M., M. Seitz, G. Martinotti, M. M. Betz, E. W. Rauterberg, and D. Gemsa. 1984. Macrophages release arachidonic acid, prostaglandin $E_{2}$, and thromboxane in response to late complement components. J. Immunol. 133:2145-2150.

4. Salant, D. J., S. Belok, M. P. Madaio, and W. G. Couser. 1980. A new role for complement in experimental membranous nephropathy in rats. J. Clin. Invest. 66:1339-1350.

5. Adler, S., D. J. Salant, J. E. Dittmer, H. G. Rennke, M. P. Madaio, and W. G. Couser. 1983. Mediation of proteinuria in membranous nephropathy due to a planted glomerular antigen. Kidney Int. 23:807-815.

6. Groggel, G. C., S. Adler, H. G. Rennke, W. G. Couser, and D. J. Salant. 1983. Role of the terminal complement pathway in experimental membranous nephropathy in the rabbit. J. Clin. Invest. 72:1948-1957.

7. Baker, P. J., R. F. Ochi, S. Adler, R. J. Johnson, and W. G. Couser. 1985. C6 depletion abolishes proteinuria in experimental membranous nephropathy. Clin. Res. 33:475A. (Abstr.)

8. Biesecker, G. 1983. Membrane attack complex of complement as a pathologic mediator. Lab. Invest. 49:237-249.

9. Rauterberg, E. W., T. Gehrig, and P. L. Kohl. 1981. The attack complex of complement in epimembranous and anti-basement membrane antibody glomerulonephritis. Kidney Int. 20:160. (Abstr.)

10. Falk, R. J., A. P. Dalmasso, Y. Kim, C. H. Tsai, J. I. Scheinman, H. Gewurz, and A. F. Michael. 1983. Neoantigen of the polymerized ninth component of complement: characterization of a monoclonal antibody and immunohistochemical localization in renal disease. J. Clin. Invest. 72:560-573.

11. Dahl, M. V., R. J. Falk, R. Carpenter, and A. F. Michael. 1984. Deposition of the membrane attack complex of complement in bullous pemphigoid. J. Invest. Dermatol. 82:132-135.

12. Parra, G., J. L. Platt, R. J. Falk, B. Rodriguez-Iturbe, and A. F. Michael. 1984. Cell populations and membrane attack complex in glomeruli of patients with post-streptococcal glomerulonephritis: identification using monoclonal antibodies by indirect immunofluorescence. Clin. Immunol. Immunopathol. 33:324-332.

13. Kopp, W. C., and R. Burrell. 1982. Evidence for antibody-dependent binding of the terminal complement component to alveolar basement membrane. Clin. Immunol. Immunopathol. 23:10-21.

14. Koffler, D., G. Biesecker, B. Noble, G. A. Andres, and A. Martinez-Hernandez. 1983. Localization of the membrane attack complex in experimental immune complex glomerulonephritis. J. Exp. Med. 157: 1885-1905.

15. Biesecker, G., B. Noble, G. A. Andres, and D. Koffler. 1984.
Immunopathogenesis of Heymann's nephritis. Clin. Immunol. Immunopath. 33:333-338.

16. Adler, S., P. J. Baker, P. Pritzl, and W. G. Couser. 1984. Detection of terminal complement components in experimental immune glomerular injury. Kidney Int. 26:830-837.

17. deHeer, E., M. R. Daha, S. Bhakdi, H. Bazin, and L. A. van Es. 1985. Possible involvement of terminal complement complex in active Heymann nephritis. Kidney Int. 27:388-393.

18. Perkinson, D. P., P. J. Baker, W. G. Couser, P. Pritzl, and S. Adler. 1985. Membrane attack complex deposition in experimental glomerular injury. Am. J. Pathol. 120:121-128.

19. Hadding, U., and H. J. Muller-Eberhard. 1967. Complement: substitution of the terminal component in immune hemolysis by 1,10 phenanthroline. Science (Wash. DC). 157:442-443.

20. Stolfi, R. L. 1968. Immune transformation: a state of irreversible damage generated as a result of the reaction of the eight components in the guinea pig complement system. J. Immunol. 100:46-54.

21. Tamura, N., A. Shimada, and S. Chang. 1972. Further evidence for immune cytolysis by antibody and the first eight components of complement in the absence of C9. Immunology. 22:131-140.

22. Couser, W. G., D. R. Steinmuller, M. M. Stilmant, D. J. Salant, and L. M. Lowenstein. 1978. Experimental glomerulonephritis in the isolated perfused rat kidney. J. Clin. Invest. 62:1275-1287.

23. Neale, T. J., W. G. Couser, D. J. Salant, L. M. Lowenstein, and C. B. Wilson. 1982. Specific uptake of Heymann's nephritic kidney eluate by rat kidney: Studies in vivo and in isolated perfused kidneys. $L a b$. Invest. 46:450-453.

24. Assel, E., K. H. Neumann, H. J. Schurek, C. Sonnenburg, and H. Stolte. 1984. Glomerular albumin leakage and morphology after neutralization of polyanions. I. Albumin clearance and sieving coefficient in the isolated perfused rat kidney. Renal Physiol. 7:357-364.

25. Sonnenburg-Hatzopoulos, C., E. Assel, H. J. Schurek, and H. Stolte. 1984. Glomerular albumin leakage and morphology after neutralization of polyanions. II. Discrepancy of protamine induced albuminuria and fine structure of the glomerular filtration barrier. J. Submicrosc. Cytol. 16:741-751.

26. Couser, W. G., C. Darby, D. J. Salant, S. Adler, M. M. Stilmant, and L. M. Lowenstein. 1985. Anti-GBM antibody induced proteinuria in the isolated perfused rat kidney. Am. J. Physiol. 249:F241-250.

27. Boyce, N. W., and S. R. Holdsworth. 1984. Mediation of injury in anti-GBM antibody induced nephritis in the isolated perfused rat kidney. Ninth International Congress of Nephrology, Los Angeles, 236. (Abstr.)

28. Salant, D. J., S. Adler, C. Darby, N. J. Capparell, G. C. Groggel, I. D. Feintzeig, H. G. Rennke, and J. E. Dittmer. 1985. Influence of antigen distribution on mediation of immunologic glomerular injury. Kidney Int. 27:938-950.

29. Densen, P., E. J. Brown, G. J. O’Neill, F. Tedesco, R. A. Clark, M. M. Frank, D. Webb, and J. Myers. 1983. Inherited deficiency of C8 in a patient with recurrent meningococcal infections: further evidence for a dysfunctional C8 molecule and nonlinkage to the HLA system. $J$. Clin. Immunol. 3:90-99.

30. Tedesco, F., P. Densen, M. A. Villa, B. H. Peterson, and G. Sirchia. 1983. Two types of dysfunctional eighth component of complement molecules in $\mathrm{C} 8$ deficiency in man: reconstitution of normal C8 from the mixture of two abnormal C8 molecules. J. Clin. Invest. 71: 183-191.

31. Nishiitsutsuji-Uwo, J. M., B. D. Ross, and H. A. Krebs. 1967. Metabolic activities of the isolated perfused rat kidney. Biochem. J. 103: 852-862.

32. Vaerman, J. P., A. M. Lebacq-Verheyden, L. Scolari, and J. F. Heremans. 1969. Further studies on single radial immunodiffusion. II. The reversed system: diffusion of antibodies in antigen-containing gels. Immunochemistry. 6:287-293.

33. Tan-Wilson, A. L., B. R. Rightmire, and K. A. Wilson. 1983. 
Determination of relative antigen-antibody avidities by radial immunodiffusion. J. Immunol. Methods. 61:99-106.

34. McConahey, P. J., and F. L. Dixon. 1966. A method of trace iodination of proteins for immunologic studies. Int. Arch. Allergy Appl. Immunol. 29:185-189.

35. Salant, D. J., C. Darby, and W. G. Couser. 1980. Experimental membranous glomerulonephritis in rats: quantitative studies of glomerular immune deposit formation in isolated glomeruli and whole animals. J. Clin. Invest. 66:71-81.

36. Kabat, E. A., and M. M. Mayer. 1961. Complement and complement fixation. In Experimental Immunochemistry, 2nd edition. Charles C Thomas, Springfield, IL. 133-240.

37. Hammer, C. H., G. H. Wirtz, L. Renfer, H. D. Gresham, and B. F. Tack. 1981. Large scale isolation of functionally active components of the human complement system. J. Biol. Chem. 256:3995-4006.

38. Snedecor, G. W., and W. G. Cochran. 1967. Statistical Methods. 6th edition. Iowa State University Press, Ames. 135-171.

39. Siegel, S. 1956. Nonparametric statistics for the behavioral sciences. McGraw-Hill Kogakusha Ltd., Japan. 116-127, 184-193.

40. Stolte, H., H. J. Schurek, and J. M. Alt. 1979. Glomerular albumin filtration: a comparison of micropuncture studies in the isolated perfused rat kidney with in vivo experimental conditions. Kidney Int. 16:377384.

41. Swanson, J. W., A. Besarab, P. P. Pomerantz, and A. DeGuzman. 1981. Effect of erythrocytes and globulin on renal functions of the isolated rat kidney. Am. J. Physiol. 241:F139-F150.

42. Maack, T. 1980. Physiological evaluation of the isolated perfused rat kidney. Am. J. Physiol. 238:F71-F78.

43. Deen, W. M., and B. Satvat. 1981. Determinants of the glomerular filtration of proteins. Am. J. Physiol. 241:F162-F170.

44. Kerjaschki, D., and M. G. Farquhar. 1983. Immunocytochemical localization of the Heymann nephritis antigen (GP 330) in glomerular epithelial cells of normal Lewis rats. J. Exp. Med. 157:667-686.

45. Camussi, G., J. R. Brentjens, B. Noble, D. Kerjaschki, F. Malavasi, O. A. Roholt, M. G. Farquhar, and G. Andres. 1985. Antibody-induced redistribution of Heymann's antigen on the surface of cultured glomerular visceral epithelial cells: possible role in the pathogenesis of Heymann glomerulonephritis. J. Immunol. 135:2409-2416.

46. Kefalides, N. A., R. Alper, and C. C. Clark. 1979. Biochemistry and metabolism of basement membranes. Int. Rev. Cytol. 61:167-228.

47. Mayer, M. M. 1972. Mechanism of cytolysis by complement. Proc. Natl. Acad. Sci. USA. 69:2954-2958.

48. Podack, E. R., G. Biesecker, and H. J. Muller-Eberhard. 1979.
Membrane attack complex of complement: generation of high-affinity phospholipid binding by fusion of five hydrophilic plasma proteins. Proc. Natl. Acad. Sci. USA. 76:897-901.

49. Inoue, K., T. Kinoshita, M. Okada, and Y. Akiyama. 1977. Release of phospholipids from complement-mediated lesions on the surface structure of Escherichia coli. J. Immunol. 119:65-72.

50. Adler, S., P. J. Baker, R. J. Johnson, R. F. Ochi, and W. G. Couser. 1985. Membrane attack complex (C5b-9) stimulates production of reactive oxygen species by rat mesangial cells. Clin. Res. 33:474A. (Abstr.)

51. Sandberg, A. L., L. G. Raisz, L. M. Wahl, and H. A. Simmons. 1982. Enhancement of complement-mediated prostaglandin synthesis and bone resorption by arachidonic acid and inhibition by cortisol. Prostaglandins Leukotrienes Med. 8:419-427.

52. Couser, W. G., M. M. Stilmant, and C. Darby. 1976. Autologous immune complex nephropathy. I. Sequential study of immune complex deposition, ultrastructural changes, proteinuria and alterations in glomerular sialoprotein. Lab. Invest. 34:23-30.

53. Schneeberger, E. E., and W. E. Grupe. 1976. The ultrastructure of the glomerular slit diaphragm in autologous immune complex nephritis. Lab. Invest. 34:298-305.

54. Sharon, Z., M. M. Schwartz, B. U. Pauli, and E. J. Lewis. 1982. Impairment of glomerular clearance of macroaggregates in immune complex glomerulonephritis. Kidney Int. 22:8-12.

55. Heptinstall, R. H. 1974. Pathology of the Kidney. 2nd edition. Little, Brown and Company, Boston. 393-412.

56. Fray, J. C. 1976. Stretch receptor model for renin release with evidence from perfused rat kidney. Am. J. Physiol. 231:936-944.

57. Forbes, R. D. C., M. Pinto-Blonde, and R. D. Guttmann. 1978. The effect of anticomplementary cobra venom factor on hyperacute rat cardiac allograft rejection. Lab. Invest. 39:463-470.

58. Forbes, R. D. C., R. D. Guttman, D. V. M. Kuramochi, J. Klassen, and J. Knack. 1976. Nonessential role of neutrophils as mediators of hyperacute cardiac allograft rejection in the rat. Lab. Invest. 34:229234.

59. Chartrand, C., S. O'Regan, P. Robitaille, and M. Pinto-Blonde. 1979. Delayed rejection of cardiac xenografts in C6-deficient rabbits. Immunology. 38:245-248.

60. Groggel, G. C., D. J. Salant, C. Darby, H. G. Rennke, and W. G. Couser. 1985. Role of terminal complement pathway in the heterologous phase of antiglomerular basement membrane nephritis. Kidney Int. 27:643-651. 